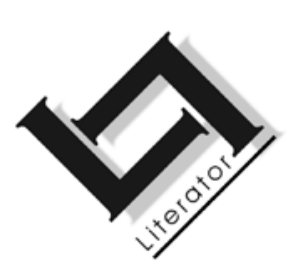

\title{
'n Verslag oor die vertaling van dertien Jacques Brel-chansons in Afrikaans
}

\author{
B. Odendaal \& N. Morgan \\ Departement Afrikaans \& Nederlands, Duits \& Frans \\ Universiteit van die Vrystaat \\ BLOEMFONTEIN \\ E-pos: odenbj.hum@ufs.ac.za \\ morgann.hum@ufs.ac.za
}

\begin{abstract}
A report on the translation of thirteen Jacques Brel chansons into Afrikaans

The authors of this article also translated the thirteen Jacques Brel chansons in question into Afrikaans. A brief explanation of the generic nature of the French chanson and an evaluation of Brel's stature as a twentieth-century chanson writer are followed by background details and a description of the translation process involved. Since literary quality is a particular characteristic of chanson lyrics, several paragraphs are dedicated to a discussion of the poetic nature of Brel's songs.
\end{abstract}

\section{Opsomming}

\section{'n Verslag oor die vertaling van dertien Jacques Brel- chansons in Afrikaans}

Die skrywers van hierdie artikel is ook die Afrikaans-vertalers van die dertien Jacques Brel-chansons wat ter sprake kom. 'n Bondige omskrywing van die genre van die Franse chanson en 'n aanstipping van Brel se statuur as twintigste-eeuse chansonnier word gevolg deur agtergrondinligting oor en 'n beskrywing van die gevolgde vertaalproses. Omdat literêre gehalte 'n besondere kenmerk van chansonlirieke blyk te wees, word 'n aantal paragrawe gewy aan 'n bespreking van die digterlike aard van die betrokke liedere. 


\section{Vooraf}

Die outeurs van hierdie artikel is ook die vertalers van die dertien Jacques Brel-chansons wat ter sprake kom.

Ter motivering van die vertaalpoging word eers iets gesê oor die aard van die chanson as liedgenre, asook oor die aansien wat Brel as twintigste-eeuse chansonnier geniet het, en steeds geniet. Daarna word die agtergrond en proses van die vertaalpoging kortliks beskryf.

Aangesien die literêre gehalte van chansonlirieke 'n uitstaande kenmerk daarvan is, word ten slotte 'n aantal paragrawe gewy aan die poëtiese kwaliteite van die betrokke Brel-chansons.

\section{Jacques Brel (08/04/1929-09/10/1978): "Keiser van die chanson"}

In talle lande van die wêreld klink die liedkuns van Jacques Brel, selfs byna dertig jaar na sy dood en reeds veertig jaar na sy allerlaaste verhoogoptrede as chansonnier in Mei 1967 (Van Altena, 2005:7), nog gereeld op in vertonings en opnames. ${ }^{1}$

Afrikaanse musiekkunstenaars het hulle eweneens daaraan gewaag om sy werk te sing en op laserskyf vas te lê: Laurika Rauch, Jannie du Toit, André Schwartz, Kevin Leo, Karin Hougaard, Coenie de Villiers, ensovoorts. Gewoonlik geskied dit in Engels of Nederlands, maar in enkele gevalle ook in Afrikaanse vertaling. 2

1 Sny 'n mens met behulp van die soekterm Jacques Brel spoor op die internet, kom jy af op tientalle advertensies van en resensies oor vertonings en CDopnames, selfs net daterend uit 2006 en 2007, waarin die liedkuns van Brel (vertaald of onvertaald) sentraal staan of saam met dié van ander chansonniers uitgevoer is. Dit geld vir lande in feitlik alle wêrelddele, onder meer Nederland, België, Duitsland, Groot-Brittanje, die VSA, Kanada, Australië en Japan.

2 Fanus Rautenbach se Afrikaanse vertaling van "Ne me quitte pas" as "Moenie weggaan nie" is in 1980 deur Laurika Rauch opgeneem op haar album 'n Jaar in my lewe (RPM1152). "Moenie weggaan nie" word in 1997 weer deur Rauch opgeneem in 'n album in sy geheel gewy aan Brel se musiek (die orige twaalf liedere in die album is in Engels), getiteld The Brel album (Select Musiek, SELBCD263). Jannie du Toit het, na aanleiding van 'n verhoogproduksie met gelyknamige titel, die album De kleine man in 1994 uitgereik (JNSMusiek, JNSD 16), waarop twee Nederlandse vertalings van Brel-werke ingesluit is, naamlik Willem Wilmink se vertaling van "Voir un ami pleurer" ("Een vriend zien huilen") en Van Altena se vertaling van "Les paumés du petit matin" ("De nuttelozen van de nacht"). Du Toit se Afrikaanse vertaling van "La chanson des vieux amants", met as titel "Liefde van later" en vertaal op basis van die Nederlandse oorsetting 
Hoewel die byna ekstatiese Brel-bewondering van veral die sestigeren sewentigerjare intussen ietwat afgeneem het, $\mathbf{3}$ is bogenoemde tog ' $n$ aanduiding dat die trefkrag van Brel se liedkuns nie afgeslyt het nie. 4

Die Amsterdamse digter Ernst van Altena, wat sowat 70 van Brel se liedere in Nederlands vertaal het en wat deur Brel self tot die bewaker van sy liedereskat in die Nederlandstalige wêreld benoem is (Haveman, 2005:275), bestempel Brel as "de keizer van het chanson" (Van Altena, 2005:7). Hy gaan voort:

Waarschijnlijk ook realiseren we ons in retrospectief beter dat Brels dood het einde van een cultureel tijdperk inluidde en wel dat van het lied als groot theatraal expressiemiddel waarin persoonlijke poëzie, inventieve, niet uit de computer gehaalde muziek en dramatische uitdrukkingskracht nog konden samengaan om een breed, niet door generatiekloven gescheiden publiek te veroveren.

van die lied deur Lennart Nijgh, is in 2004 onderskeidelik deur Kevin Leo (2004) in die album Sê, c'est la vie (Leoness Musique, LMCD 001) en deur Coenie de Villiers (2004) in die album Handgemaak (JNS Musiek, JNSD121) opgeneem. Karin Hougaard laat in 1999 'n laserskyf die lig sien (getiteld Metamorph. Contemporary Brel \& Piaf - JNS Musiek, JNSD 81). Sy sing verskillende Brelliedere in die oorspronklike Frans, maar ook in Engelse en Nederlandse vertaling, terwyl een lied, "Vriend sien huil" ("Voir un ami pleurer"), in Afrikaanse vertaling gesing word (deur Hougaard self vertaal). Hougaard het ook heelwat sukses met die verhoogproduksie na aanleiding van hierdie liedere behaal (onder meer toekennings op die Klein Karoo en die Aardklop Nasionale kunstefeeste - http://www.karinhougaard.com/Biografie.html; datum van gebruik: 10 Januarie 2007).

3 Op die eerste dag na die verskyning van sy laaste album (die langspeelplaat Brel) in 1977 is meer as 600000 kopieë daarvan verkoop (Wikipedia, 2007:4). Tans is die situasie, volgens 'n effens siniese Haveman (2005:275), ietwat anders: "Op een korte opleving na, zo rond de Tour de France, is de chansoncultuur van Brassens tot Bécaud en van Brel tot Barbara en Béart inmiddels weggestopt bij herinneringen aan druipkaarsen met visnetten en zwaar opgemaakte meisjes in Juliette Gréco-coltruien."

$4 \quad$ Wikipedia (2007:4) berig: "Ook in de 21ste eeuw wordt Brels werk nog volop door andere artiesten uitgevoerd. Franstalige radioluisteraars uit diverse landen riepen Ne me quitte pas uit tot het beste lied van de twintigste eeuw en kijkers van de RTBF kozen Brel op 20 december 2005 als De Grootste Belg. In de Vlaamse tegenhanger van deze verkiezingen eindigde hij als 7de." En Anthierens (1998:76) skryf dat, slegs sowat twintig jaar na Brel se dood, reeds 400 professionele sangeresse en sangers "Ne me quitte pas" in tallose tale gesing het. 
Die chanson van die Franstalige wêreld, soos dit oor baie eeue maar veral oor die afgelope sowat 100 jaar sy beslag gekry het as "chanson artistique", "chanson littéraire" of "chanson poétique" (Stemmet, 1992:52, 54), word gekenmerk deur die feit dat woord en musiek met ewe veel respek gehanteer word. Dikwels neem die digterlike woord 'n sentrale plek daarin in; daar is 'n duidelike oogmerk om "'poëtisch' te functioneren" (Van Gorp et al., 1993:67). Van die belangrikste Franse digters se werk is byvoorbeeld op hierdie wyse getoonset en populêr gemaak: Verlaine, Rimbaud, Baudelaire, Hugo, Apollinaire, Ronsard, De Musset, Villon en andere.

Uit wat onder meer Van Altena (2005:9-11), Dupré (2006:1-3) en 'n onbekende outeur van Wikipedia (2007:3) skryf, kan 'n mens die volgende as opvallende kenmerke van spesifiek Brel se chansonoeuvre uitsonder:

- Die prominensie van temas soos die liefde(-sleed) - tendresse, dit wil sê "teerheid", is by hom die sleutelwoord in hierdie verband, eerder as amour - maar ook vriendskap of kameraderie, verknogtheid aan die Vlaamse landskap 5 en 'n byna obsessiewe bemoeienis met die dood.

- Die dikwels empatieke, maar soms ook sarkastiese portretterings van mensetipes (bejaardes, wanhopiges, die "nutteloses van die nag", ens.) en die satirisering van (die geveinsdhede van) die burgerlike moraal - laasgenoemde veral in die vorms wat dit aanneem as kerklike leer en praktyk, maar ook in die vorms van Vlaamse tradisionalisme en chauvinisme.

- Die treffende sketsing van dramatiese situasies en fasette van die amoreuse lewe in 'n vorm wat soms as "gesonge eenakters" bestempel word.

- Op stilistiese vlak die vindingryke en dikwels treffende benutting van beeldspraak, ironie en die ritmiese en klankaspekte van taal.

Hoewel Van Altena in 'n gesprek met Hennie Aucamp (1984:9) laat blyk het dat hy chanson wil definieer as "n lied wat ook sonder sy musiek kan bestaan", moet 'n mens versigtig wees om nie die literêre kwaliteite van die chanson te oorbeklemtoon of te oorskat nie. Reeds in die sewentiende-eeuse Frankryk is daar benadruk dat "suiwer poësie selfstandig is en sonder musiek kan klaarkom", en is die chansonteks "finaal uitgestoot uit die geselskap van die ernstige

$5 \quad$ Brel is in Brussel gebore (Todd, 1984:13). 
letterkunde" (Stemmet, 1992:52). In sy opstel "Die digter en die liedskrywer" sluit Aucamp (1984:62) hom aan by 'n stelling van die literêre teoretici Wellek \& Warren (1980:127) dat

... the highest poetry does not tend towards music, and the greatest music stands in no need of words.

Die chanson poétique het dus, literêr-esteties gesproke, iets onbeslis of dubbelslagtigs (tensy dit gaan om getoonsette, voorheen onafhanklik gepubliseerde gedigte). Dit funksioneer iewers tussen kommersialiteit en ernstige poësie (Stemmet, 1992:52).

Brel het in 'n onderhoud self die relatiewe digterlike gehalte van chanson-tekste beklemtoon:

Een echte dichter laat zich niet met liedjes in, iemand met een waarachtig talent heeft bij ons niets verloren. Chansonniers zijn mensen die in hun leven tien minuten lang Rimbaud willen zijn, en zich na die tien minuten vlijtig op de chanson toeleggen. (Vertaald aangehaal deur Anthierens, 1998:174.) ${ }^{6}$

Dit is eerder die balans tussen die primêre aspekte waaruit dit saamgestel is, naamlik die fyn- en heggestrukteerde, suggestiewe en boeiende liedteks en die vindingryk-ekspressiewe toonsetting, wat die trefkrag van die chanson teweegbring. (Die bydrae van die gevoelige vertolker buite rekening gelaat.) Brel het dikwels chansons geskryf wat te bewonder is "om hulle woordspelings en soms anormale taalgebruik; om hul organisasie van 'n gevoelsargument", soos Aucamp (1977:9) die voortreflikste soort liedtekste tipeer - en wat volgens Aucamp (1984:61) soms wel "toevallig" kan uitgroei tot "goeie poësie", hoewel byna nooit tot "groot poësie" nie (sy kursivering).

Met die treffend-ekspressiewe musikale begeleidings wat daarmee gepaard gegaan het, asook vanweë die gevoelige interpretasies wat hy as uitvoerende kunstenaar self daaraan gegee het, het Brel talle

Onderhoud oorspronklik gevoer met Denise Glaser vir die program Discorama wat op 15 September 1963 op Franse televisie uitgesaai is. Die betrokke gedeelte van die onderhoud is ook vertaald aangehaal deur Dupré (2006:1). In die oorspronklike Frans lui dit: "Si quelqu'un était poète, il ne serait sûrement pas de la chanson, vous comprenez. Si quelqu'un avait vraiment beaucoup de talent, il ne serait non plus certainement pas dans la chanson, c'est certain. [...] les gens qui font de la chanson, ils ont peut-être tous voulu pendant dix minutes être Rimbaud et comme ils ne sont justes pas Rimbaud, ils essaient de faire des chansons jolies ou honnêtes." 
kere op buitengewoon meesleurende wyse verwerklik wat Aucamp (1977:9) in sy opmerkings oor kabaret laat skryf het: "(S)ang is verhewigde spraak".

\section{Die agtergrond en proses van die vertaling van 'n dertiental Brel-chansons in Afrikaans}

Die besondere (artistieke) aard van die chanson, asook die voortreflikhede van Brel se chansonwerk, is onses insiens al rede genoeg om ('n gedeelte van) die Brel-oeuvre toeganklik te maak vir Afrikaanse gehore. Hieroor weldra meer.

Die projek waarvoor ons hier 'n verantwoording verskaf, het egter ook 'n meer subjektiewe aanloop. Prof. Naòmi Morgan, werksaam by die afdeling Frans aan die Universiteit van die Vrystaat, is in 1978 (deur haar destydse Frans-lektrise aan dieselfde instelling, mme. Claire Massardo), na aanleiding van Brel se dood daardie jaar, bekendgestel met sy liedkuns. Sy het haar voorgeneem om Frans sodanig te leer beheers dat sy Brel ten volle kon begryp. As eerbetoon aan mme. Massardo, ' $n$ Waalse boorling, het Morgan haar mettertyd ook voorgeneem om Afrikaanse vertalings van Brel se lirieke daar te stel, op so 'n wyse dat die dikwels digterlike gehalte daarvan gerespekteer sou word. Om hierdie rede het sy prof. Bernard Odendaal, dosent en poësiespesialis by die afdeling Afrikaans en Nederlands van dieselfde universiteit, in 2004 genader om as haar medevertaler op te tree.

Morgan sou letterlike vertalings lewer, voorsien van verklarende aantekeninge 7 oor kultuurspesifieke items wat nie geredelik begryplik vir Afrikaanssprekendes in die algemeen is nie. Op basis hiervan moes Odendaal die Afrikaanse lirieke skryf.

Aanvanklik is, ietwat lukraak, maar tog in 'n poging om 'n keuse te maak wat verteenwoordigend van die mees uitstaande temas in Brel se oeuvre sou wees, op 'n twaalftal van Brel se chansons as 'n eerste fase in die vertalingsprojek besluit. Hulle is (oorspronklike

$7 \quad$ Volgens Naudé (2001:189) kan 'n letterlike vertaling soos volg gedefinieer word: "Die grammatikale konstruksies van die brontaal word in die naaste doeltaalekwivalent omgesit, maar die leksikale woorde word [...] een-vir-een buite konteks vertaal. As 'n voorvertalingsproses dui dit die probleme aan wat opgelos moet word." Morgan se verklarende aantekeninge was heel dikwels aanduidings van spesifieke probleme wat deur Odendaal in die Afrikaanse omsettings "opgelos" moes word. 
Franse titels telkens gevolg deur die gekose Afrikaanse titelvertalings, waar van toepassing, en met 'n aanduiding van welke tematiese aspek[te] dit belig):

- "Le moribond" ("Die sterwende"). 'n Soort opsomming van die groot temas in sy liedkuns: die chroniese ontrouheid van vroue, die lojaliteit van vriende, sy afkeer aan die kerk (se dogma en ampsdraers), die dood ... 'n Dodedansagtige beswering van sy vrese.

- "La bière" ("Drinklied"). Die drinklied as genre pas by die lewensgenietende Vlaminge (Mouton et al., 2001:11). Hierdie lied is in der waarheid 'n soort distillasie van 'n hele kulturele en sosiale erfenis, onder meer via die kulturele verwysings na die boerse poetsbakkersfiguur, Tyl Uilspieël, en sy trawante, asook na die beroemde skilder van onder meer boerse fees- en fuifgeleenthede, Pieter Brueghel die Ouere, in die eerste strofe van die oorspronklike Franse liedteks.

- "Les vieux" ("Die grysaards"). In 'n era toe die verheerliking van jeugdigheid op dreef gekom het (dink aan die hippiebeweging van die sestigerjare), het Brel dié roerende lied oor oumense en oudword - en uiteindelik oor die steeds bedreigende verganklikheid van die aardse lewe - geskryf.

- "Le plat pays" ("My lae land") (Brel, 2005). 'n Deernisvolle, beeldryke besinging van die nuanses van die Vlaamse landskap- en klimaatsverskynsels. Meer as een Belg (onder meer prof. Marcel Janssens van die Katholieke Universiteit Leuven tydens 'n besoek aan die Vrystaatse Universiteit in Mei 2002) het al die mening uitgespreek dat "Le plat pays", deur Van Altena in Nederlands vertaal as "Mijn vlakke land", as 'n Vlaamse nasionale lied sou kon dien.

- "Jojo". Een van Brel se chansons oor die kameraderie tussen mans (selfs tot in die doderyk toe!) - iets wat hy as van blywender waarde as die liefde tussen man en vrou geag het. Jojo was die noemnaam van Georges Pasquier, 'n man wat 'n loopbaan as ingenieur prysgegee het om Brel se chauffeur en sy "compagnon de voyage" te wees. (Kyk Anthierens, 1998:54, 83.)

- "Amsterdam". 'n Seemansliedjie met die rooiliggebied digby die Amsterdamse hawe en die vermaak en vertroosting wat die seelui aldaar soek, as agtergrond. 
- "Mon enfance" ("My kinderdae"). Hierdie lied het drie jaar na sy ouers se dood in 1964 ontstaan; dit verteenwoordig 'n soort "navrante [...] inventaris [...] van toentertijd" op die Wes-Vlaamse platteland, waar die Brels dikwels besoeke gebring het (Anthierens, 1998:60).

- "Quand on n'a que l'amour" ("Om met liefde alleen"). Die inhoud van dié lied is al herhaaldelik as stroperig en naïef inspirasioneel afgekam - bestempel as daterende uit die vroeë "rozenwaterperiode" van sy kunstenaarskap (Anthierens, 1998:67).

- "Les Flamandes" ("Vlamingvrou"). 'n Spotlied (Anthierens, 1998: 89-90) wat by die verskyning daarvan opspraak verwek het en selfs oor Vlaamse radio en televisie verbied is omdat dit kwansuis beledigend teenoor Vlaamse vroue sou wees (Anthierens, 1998: 173).

- "Il neige sur Liège" ("Sneeu oor luik"). Een van die min Brel-liedere met Wallonië, die Franstalige deel van België, as agtergrond. 'n Stemmingsvolle chanson oor 'n sneeubedekte stad aan die Maasrivier, maar waarin die Maas treffend uitgebou word tot 'n verganklikheidsimbool.

- "Les timides" ("Die bedeesdes"). 'n Treffende voorbeeld van Brel se ironie- maar ook mededoë-gelade beskouings van die verskoppelinge of sukkelaars van die wêreld.

- "La chanson des vieux amants" ("Die lied van die ou minnaars"). Volgens Anthierens $(1998: 71,72)$ die "hooglied van de gelouterde minnaars" en 'n hoogtepunt in Brel se oeuvre - "een synthese van zijn spirituele, emotionele en artistieke slagkracht".

$\mathrm{Na}$ afloop van die vertaalwerk het Morgan 'n vertellersteks geskryf om die uiteenlopende chansons tot 'n kabaretproduksie saam te snoer. As enscenering is 'n situasie bedink waar (die steeds lewende) madame Thérèse Brel die "Vlaamse Liedskrywersvereniging" se jaarvergadering toespreek oor "My man, Jacques Brel". Deur middel van ' $n$ wisseling van kolbeligting is, waar die mymeringe van "madame Brel" die oorgange na spesifieke liedere moontlik maak, fokusverskuiwings na uitvoerings van die twaalftal liedere bewerkstellig.

Die Johannesburgse sanger Herman van den Berg, op klavier begelei deur Matthys Maree, is genader om die chansons uit te voer. Van den Berg, ' $n$ opgeleide klarinettis, het voorgestel dat 'n dertiende Brel-chanson, naamlik "Le bon Dieu" ("Die goeie god" - "god" 
so met die kleinletter vertaal), oorgesit word in Afrikaans om as moontlike vertoningstoegif te dien. Dié lied, vanaf Brel se laaste album, verteenwoordig nog 'n variasie op sy kritiese opstelling teen kerklike dogma en praktyke. Die aantreklikheid van die chanson lê in die pragtige walsmusiek, gelei deur die klarinet.

Met 'n drietal vertonings tydens die 2005-Volksblad-kunstefees in Bloemfontein is dié produksie, getiteld "My man, Jacques Brel - in klinkende Afrikaans!", van stapel gestuur. Tot en met die skrywe van hierdie artikel is dit 'n verdere 20 kere uitgevoer, hier te lande en in België en Nederland, telkens met Morgan in die rol van madame Brel. 'n Laserskyfopname van die dertien vertaalde chansons, getiteld herman van den berg sing brel in Afrikaans (2007a), is middelFebruarie 2007 (2007b) in Suid-Afrika uitgereik; in November 2007 het 'n Beneluxlande-uitgawe, onder die etiket "Tussen kontinente" en met Herman van den Berg. Brel in Afrikaans, as titel die lig gesien.

Hoewel 'n verdere vyftiental van Brel se chansons deur die artikelouteurs vertaal en in 'n tweede Brel-produksie, getiteld "Jacques Brel: die tere oorlog van die liefde", benut is, $\mathbf{8}$ val die fokus in hierdie artikel op eersgenoemde dertien vertalings.

\section{Opmerkings oor die intrinsieke (literêre) kwaliteite van die vertaalde Brel-chansons}

Die intrinsieke (poëtiese) kwaliteite van Brel se chansonswerk was die belangrikste oorweging in ons besluit om dit vir Afrikaanse gehore toeganklik te maak. Ons het ons ook vanuit die staanspoor voorgeneem om die besondere digterlike gehalte van Brel se liedere te respekteer - om dus toeganklike Afrikaanse ekwivalente daar te stel, sonder transkulturasie, ${ }^{9}$ wat 'n ewe sterk estetiese funksie sal hê. 'n Mens sou wat ons in die oog gehad het, dus in terme van Newmark (1988) se onderskeidings (kyk Naudé, 2001:189), as 'n kommunikatiewe vertaling kan beskryf. Dit beteken dat gepoog sou word om die presiese kontekstuele betekenisse van die oorspronk-

Dié produksie is die eerste keer tydens die Volksblad-kunstefees van 2006 opgevoer, naamlik op 14-16 Julie. Die mees onlangse Suid-Afrikaanse opvoering was op 6 Oktober 2007 in die William Humphreys Kunsmuseum in Kimberley, terwyl etlike uitvoerings in België gevolg het tussen 26 November en 4 Desember 2007.

9 'n Begrip wat aanpassings in die kulturele dimensie aandui, sodat die teks as 't ware eie aan die doelkultuur word (Newmark, 1988:103; Naudé, 2001:191). 
like weer te gee op wyses wat die inhoud en die taalgebruik aanvaarbaar en verstaanbaar maak vir Afrikaanse luisteraars met 'n basiese ingeligtheid oor die Europese, spesifiek Frans-Europese, verwysingswêreld. 10

Heelparty van Brel se chansons het 'n treffende, meesleurende krag en/of skoonheid. Dupré (2006), wat hom in sy (oorspronklik Nederlandstalige) artikel juis bemoei met die vraag in welke mate Brel ook as 'n digter beskou kan word, bestempel liedere soos La Fanette, Le plat pays, Mon père disait en La ville s'endormait as "meer suggestief as mededelend", "tereg bewonderenswaardig", "poëties evokatief", "enig en wondermooi", ensovoorts.

Die benutting van talle digterlike middele dra by tot die estetiese trefkrag van sy chansons. Beperkte publikasieruimte laat ons toe om telkens slegs enkele illustratiewe voorbeelde aan te haal.

\title{
4.1 Treffende beelding
}

In die eerste plek is die vindingryke maar veral treffende - dikwels ook kontekskonkretiserende - beelding te noem. Aucamp (1984:55$56,61)$ skryf dat lirieke juis aan helderheid en onmiddellikheid kan wen deur raak beelding, aangesien "die konkrete soveel makliker verstaan word as die abstrakte; die spesifieke soveel makliker as die algemene; die beeldende soveel makliker as die betogende". In die

10 Twee response na aanleiding van die laserskyfuitgawe van die vertaalde chansons is dalk illustratief van die werking wat ons gehoop het om te bereik. Die heer Ludo Helsen, "de eerste gedeputeerde bevoegd voor cultuur, erediensten, technologie en innovatie, Europese en internationale samenwerking" van die provinsie Antwerpen in België (luidens die briefhoof wat ons in Maart 2007 van hom ontvang het), skryf onder meer:

\begin{abstract}
[1]n het begin voelde het een beetje vreemd aan om die o zo vertrouwde Brel-liederen in een nieuw jasje te ontdekken, maar het resultaat bevalt me ten zeerste. Het is voor mij verrassend hoe jullie enkele Europese verwijzingen verafrikaanst hebben, en hoe mooi jullie het eigenlijke rijmschema behouden hebben. Hieruit blijkt jullie respect voor onze grote Jacques Brel, en dat zal ongetwijfeld in goede aarde vallen bij het Belgische publiek.
\end{abstract}

En die Afrikaanse prosaïs, Izak de Vries, het in Oktober 2007, in 'n bydrae tot die sogenaamde "Letterkunde en integriteit"-seminaar op LitNet, die volgende getuig oor die Brel-vertalings:

Ek ken Brel se musiek redelik goed en ek kan werklik sê dat van al die Nederlandse, Afrikaanse en Engelse vertalings wat daar bestaan, daar nie een ander stel berymings is wat die integriteit - die ongeskondenheid dus - van Brel se oorspronklike musikaliteit beter behou nie. (De Vries, 2007.) 
refreingedeeltes van "Les vieux"/"Die grysaards" word die onontkombare verganklikheid grafies voorgestel in die beeld van die slingerende pendulum van die staanklok in die voorhuis - 'n tans ouwêreldse artefak wat sowel die nadering van die lewenseinde vir die oues van dae as hulle spesifieke lewensruimte treffend oproep. Vergelyk die slot van strofe 1 (Franse teksgedeelte in kursief gevolg deur letterlike Afrikaanse vertaling met bekommentariërende notas, en daarna volg die gekose Afrikaanse omsetting van die betrokke liriekgedeelte, weer in kursief):

Et s'ils tremblent un peu

est-ce de voir vieillir la pendule d'argent

Qui ronronne au salon,

qui dit oui qui dit non, qui dit: je vous attends.

Letterlike vertaling:

En bewe hulle effens

omdat hulle die silwer pendulum sien ouer word?

Die een wat dreuntik in die sitkamer,

wat ja sê, wat nee sê, wat sê: ek wag vir julle.

Afrikaanse liriekomsetting:

En bewe hulle dalk

omdat die slingering van tyd al dowwer glans?

Die staanklok wat daar tik

klik-klak 'ja', klik-klak 'nee', en sê 'jul laaste kans'.

Meermale is die geografiese en kulturele verwysings wat Brel in hierdie verband benut so spesifiek dat dit glad nie vanselfsprekend is dat luisteraars buite die Europese of selfs Franstalige wêreld die betekenisimplikasies daarvan (ten volle) sal begryp nie. In sulke gevalle het ons dus meer algemeen toeganklike omsettings gekies. Ons wys op slegs een (strofe 2 van "Jojo") uit talle moontlike voorbeelde uit die chansons wat in hierdie artikel ter sprake is:

Jojo,

Ce soir comme chaque soir

Nous refaisons nos guerres

Tu reprends Saint-Nazaire

Je refais l'Olympia

Au fond du cimetière

Jojo,

vanaand soos al die ander aande

trek ons weer die wapenrusting aan. 
Jy wen Saint-Nazaire terug

Ek tree weer op in die Olympia

vanuit die begraafplaas.

(Saint-Nazaire: 'n stad aan die Loire-rivier bekend vir sy skeepswerwe, wat byna vernietig is gedurende die Tweede Wêreldoorlog. Olympia: bekende musiekteater in Parys.)
Jojo,
op 'n aand soos vanaand
is dit als weer opwindend
wil jy Nazi's verdryf
ek teaters oorwin
uit die kerkhof vandaan.

\subsection{Die benutting van intertekstualiteit}

Verwant aan spesifieke geografiese en kulturele verwysings in Brel se chansons, moet sy konteks-outentifiserende hantering van literêre en ander estetiese toespelings gereken word. As vertalers moes ons ' $n$ aantal kere besluit oor die moontlike bekendheid, al dan nie, van sulke verwysings of toespelings, met ander woorde of ons die intertekstuele referensies in die Afrikaanse omsettings gaan behou, of nie.

In die eerste strofe na die openingsrefrein van "La bière"/"Drinklied" sing Brel in die oorspronklike Frans:
C'est plein d'Uylenspiegel
Et de ses cousins
Et d'arrière-cousins
De Brueghel l'Ancien.

Letterlik vertaald lui dit daar: "Dis gepak met Uilspieël en sy neefs en die kleinneefs van Brueghel die Ouere." Ons was onseker oor hoeveel Afrikaanssprekendes tans nog vertroud is met die verhale oor die geslepe, roekelose Nederduitse boereskelmtipe, Tyl Uilspieël (vgl. byvoorbeeld Grabert \& Mulot, 1971:94), asook oor hoeveel Afrikaansmagtiges die Vlaamse boere- en dorpsfeesskilderye van die ouer Pieter Brueghel ken. In elk geval het ons gereken dat slegs een van hierdie verwysings al genoeg is om die Laaglandse konteks in die spesifieke strofe te sinjaleer vir die luisteraars wat wel die toespelings snap. Vandaar dat ons in ons oorsetting die volgende keuses gemaak het (en 'n enkele verouderende Afrikaanse woordkeuse ingevoeg het om die Laaglandse sfeer te help oproep): 
Gepak sit Jan Rap

En maats en krakeel

Party is heel knap

Na Brueghel verbeel.

Die betekenis en herkoms van die volgende literêre aanhaling, deur Brel benut in die tweede reël van die tweede strofe van "Les vieux"/"Die grysaards", sou egter na ons mening totaal onbekend gewees het vir die oorgrote meerderheid Afrikaanse luisteraars:

Le petit chat est mort (letterlik: Die katjie is dood).

Dit is eintlik 'n aanhaling uit Molière (verhoognaam van Jean-Baptiste Poquelin, beroemde Franse komiese dramaturg uit die sewentiende eeu - vergelyk onder meer Brereton, 1966:160) se L'école des femmes (Die skool vir vroue). Wanneer Angélique, 'n onskuldige kloostermeisie in dié komedie, se aanstaande man (wat haar pa kon gewees het en vir haar opvoeding betaal het om seker te maak dat hy 'n onderdanige vrou kry) haar vra hoe haar dag verloop het, som hierdie sin nog 'n onbewoë dag in haar jong lewe op (Molière, s.a.:176). Dit word sedertdien in die Franse omgangstaal gebruik om te suggereer dat daar nie veel gebeur het nie.

Vir die Afrikaanse liriek het ons in hierdie geval op die volgende veralgemening $\mathbf{1 1}$ besluit (en ietwat vir die beeldverlies probeer vergoed deur die benutting van 'n oksimoron):

Daar's baie niks te doen.

\subsection{Dramatiese voorstelling}

In onderdele van chansons soos, onder meer, "Les vieux"/"Die grysaards", "Amsterdam" en "Les timides"/"Die bedeesdes" is Brel se dramaties-voorstellende vermoë 12 reeds waar te neem. Net een voorbeeld: Let op die ekonomie van handelingsuitbeelding waarmee die trae, maar gewisse fisiese verval van die oues van dae in die tweede strofe van "Les vieux"/"Die grysaards" geteken word. (Ons

11 In vertaalteorieterme is 'n veralgemening die gebruik van 'n kultuurneutrale, 'n minder ekspressiewe of selfs 'n meer algemene item om die kultuurspesifieke brontaalterm te omskryf (Naudé, 2001:190).

Brel was ook 'n akteur, byvoorbeeld in die (deur hom vertaalde en bewerkte) musiekblyspel "The man from la Mancha"/l'Homme de la Mancha, asook in films deur verskeie regisseurs, insluitend deur Brel self (Anthierens, 1998:15-17; Van Altena, 2005:12). 
haal slegs uit die Afrikaanse liriekomsetting aan, soos ook ten opsigte van die ander voorbeelde in hierdie afdeling.)

Die grysaards droom nog skaars

hul boeke dommel weg en hul klaviere slaap

Daar's baie niks te doen

hul skink nog muskadel, maar dit laat hul net gaap

Die grysaards roer nog skaars

in plooie vasgewoel, al nouer span die net

Van bed tot vensterbank,

daarna van bed tot stoel en dan net bed tot bed.

"Jojo" is in sy geheel die beste voorbeeld onder die betrokk chansons van die "gesonge eenakters" waartoe Brel, volgens Van Altena (2005:10), in staat was: "kleine theaterjuweeltjes die Brel ook werkelijk uitspeelde als een zingend acteur". In dié lied word 'n nagtelike besoek deur Brel self aan die begraafplaas waar sy jarelange boesemvriend begrawe lê, gesuggereer. Hy spreek Jojo aan asof laasgenoemde hom kan hoor en dit is gou duidelik dat hy hom bepaalde handelinge en dialoog inprent.

Eerste strofe.
Jojo,
ek het grappe gebring
sigarette en wyne
En die nag is nog lank
Dat ons sterre kan skyn
Voor die son ons verdring
Jojo,
ek kan hoor hoe vervoerd
jy jou vlootliedjies uitsing
dat die mense hier bo
hulle ore voel tuit
van wat ondergronds woed!

Amper soos in 'n klassieke eenbedryf word 'n streng eenheid van tyd en plek gehandhaaf. Die hele toneel speel in die begraafplaas af en vind in een (gedeelte van 'n) nag plaas. In die slotstrofe neem die spreker afskeid.

Jojo,

daar's al lig op die veld

en ek sê maar "tot later"

Al die pligpleging wag

met die koues van hart

met die draers van geld 


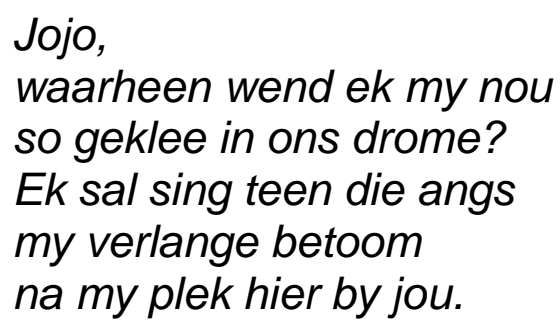

Die luisteraar bly uiteraard egter bewus daarvan dat die situasie fiktief is, in die verbeelding afspeel; dat dit ten diepste 'n hartewens verteenwoordig. Vandaar dat die refrein - waarin die mislukking van die dood verkondig word om, onderskeidelik vanaf die eerste tot die laaste herhaling, Jojo se sang, Jojo se hoop, hulle viering van broederskap en hulle wedersydse liefde te blus - so skrynend aandoen. Dit verteenwoordig 'n onhaalbare versugting van algemeen-menslike aard.

\subsection{Toonaard}

Aucamp (1984:61) wys tereg daarop dat die skep van 'n bepaalde toon die eenheid van 'n liedteks kan versterk en sodoende kan meewerk om die literêre gehalte daarvan te verhoog.

'n Verskeidenheid toonaarde word in die betrokke Brel-chansons vasgevang (aanhalings hierna uit die Afrikaanse liriekomsettings):

- 'n kaleidoskoop van sterfbed-emosies, waaronder droefheid, verwyt, dankbaarheid, deernis, humorvolheid en ontwapenende eerlikheid, wat as somtotaal vermeng tot 'n ironie-gelade, rebelslewenslustige toon in "Le moribond"/"Die sterwende";

- 'n rare vermenging van ruie bonhomie en skaars onderdrukte onbehae of satheid in "La bière"/"Drinklied";

- ontstemmende openhartigheid gepaard met simpatieke ontroering in "Les vieux"/"Die grysaards";

- bewoë verlange, van sentimentaliteit bewaar deur humorvolle ironie, in die treurlied "Jojo";

- die aangrypende wyse waarop (Wes-)Vlaandere hom deur middel van neerdrukkende, "slegte" klimaatstoestande (ook deur middel van kerklike dogma) as 't ware met afnemende krag verset teen toeëiening deur die spreker in "Le plat pays"/"My lae land" - totdat daar in die slotstrofe, as die vreugdevolle koms van die lente en somer ervaar word, as 't ware mildelik toegegee word aan die aandrang van die subjek; 
- simpatie met én afkerigheid van gedoemde pogings deur matrose om bevrediging te put uit die botviering van hulle luste in "Amsterdam";

- ontroerende bitterheid oor 'n terneerdrukkende jeugtyd te midde van verbeeldinglose maatskaplike en huislike konserwatisme, slegs kortstondig afgewissel met die ontdekking van geslagtelikheid in die gedaante van 'n eerste (meisie-)geliefde, en getemper deur blyke van verknogtheid aan die voorgeslagte, in "Mon enfance"/"My kinderdae";

- verrukte vertroue in die reddende en alles oorwinnende mag van die liefde in "Quand on n'a que l'amour"/"Om met liefde alleen" (die ongekompliseerde toon van dié lied verklap reeds dat dit tot die vroeë fase van Brel se oeuvre behoort);

- sarkastiese gespot met maatskaplike en godsdienstige konserwatisme in "Les Flamandes"/“Vlamingvrou", maar wat tóg simpatiek aandoen - onder meer deur die ironiese verwysings na (manlike, selibate) kerklui wat "vir seker" weet wat 'n vrou "moet hê" of "begeer"! - as geïmpliseer word dat Vlaamse vroue die slagoffers van sodanige konserwatisme is;

- tere vervoering oor die "skoon land" waarin die Luikse stadsomgewing omskep is deur 'n sneeuval in "Il neige sur Liège"/ "Sneeu oor Luik" - 'n stemming wat aan skryning wen deur die driemalige verwysing na die swartkleurige Maasrivier wat, met toenemende onheilspellendheid, "kil en stil [vloei]" deur dit alles, wat "sny deur die waan" en ten slotte sowel die toegesneeude toneel as die spreker "deurklief";

- simpatieke maar nie-verhullende spot met die beskroomde sukkelaars van die wêreld in "Les timides"/"Die bedeesdes" - hul angstige onsekerheid word in die halfryme en soms hortende ritmes van die lied vasgevang;

- tere eerlikheid oor sowel die lief- as die leedkante van 'n durende verhouding tussen man en vrou in "La chanson des vieux amants"/"Die lied van die ou minnaars"; en

- diepe mededoë in "Le bon Dieu"/“Die goeie god" met die magtelose mensheid wat onbegrypend moet staan voor die gedagte dat die goddelike bestiering sterflikheid en lyding nié uitsluit nie.

Dit is dadelik duidelik dat, op die inspirerende "Quand on n'a que l'amour"/"Om met liefde alleen" na, die toon van die liedere telkens van 'n komplekse aard is, hoofsaaklik vanweë die draad van ironie 
wat deur hulle almal gevleg is. Dié ironie kan soms omsit in sarkastiese gespot, maar word getemper deur mededoë. 'n Ontwapenende mengsel van eerlikheid oor en deernis met die mens ontstaan. Martin Monestier (1979:7) gebruik die frase "la résignation qui se rebelle", of "opstandige berusting", in hierdie verband - 'n kenmerk wat bestempel kan word as dié uitstaande een van Brel se liedkuns, of minstens van die chansons wat hier ter sprake is. In wese behels dit ' $n$ satiriese betrokkenheid by maatskaplike verskynsels en, uiteindelik, by die menslike toestand. 'n Werklik universele tematiek dus, wat miskien 'n gedeeltelike verklaring bied vir die durende wêreldwye geboeidheid met Brel se werk.

Jean Clouzet, skrywer van die eerste boek oor Brel, en wel as deel van die gesaghebbende Seghers-poësiereeks, se opinie versterk laasgenoemde siening. Clouzet, 'n kardioloog en musiekkenner van formaat, het nie gehuiwer om 'n ereplek tussen die digters aan die liedskrywer Brel toe te ken nie. Hy het hom - in Afrikaans vertaal13 - soos volg uitgelaat: "Deur sy teerheid, sy eensaamheid en ten slotte die somtotaal van sy temas sluit Jacques Brel aan by die belangrikste poësiestrominge van ons tyd, met behulp van sy eie, persoonlike uitdrukkingsmiddele." (Clouzet \& Clouzet, 2003:65.)

\subsection{Treffende benutting van stylfigure}

Naas die algemene ironiese inslag van Brel se liedkuns, moet gewys word op sy vindingryke benutting van veral paradoks en ironie as stylfigure.

Je veux qu'on rie

Je veux qu'on danse

Quand c'est qu'on me mettra dans le trou.

So lui dit in die refrein van "Le Moribond"/“Die sterwende". Of letterlik in Afrikaans vertaal:

Ek wil hê mense moet lag,

ek wil hê mense moet dans

die dag wanneer hulle my in die gat sit [begrawe].

Dié gedeelte van die refrein het ons soos volg in die Afrikaanse liriek omgesit:

13 In die oorspronklike Frans: "C'est par la tendresse, la solitude et, en définitive, la totalité de ses thèmes que Jacques Brel rejoint, avec des moyens d'expression qui lui sont personnels, les grands courants de la poésie de ce temps." (Clouzet \& Clouzet, 2003:65.) 
Jul moet lag

Jul moet dans

As jul my die gat in stop.

Uit talle ander moontlike voorbeelde uit die betrokke dertien chansons, miskien nog net die eerste strofe van "Amsterdam" met sy treffende beelde en kontraswerkings.

Dans le port d'Amsterdam

$Y$ a des marins qui chantent

Les rêves qui les hantent

Au large d'Amsterdam

Dans le port d'Amsterdam

$Y$ a des marins qui dorment

Comme des oriflammes

Le long des berges mornes

Dans le port d'Amsterdam

$Y$ a des marins qui meurent

Pleins de bière et de drames

Aux premières lueurs

Mais dans le port d'Amsterdam

$Y$ a des marins qui naissent

Dans la chaleur épaisse

Des langueurs océanes.

Letterlike vertaling:

In Amsterdam se hawe

sing daar matrose

van die drome wat by hulle spook

op see, ver van Amsterdam.

In Amsterdam se hawe

slaap daar matrose

soos baniere

langs die verlate kaaie.

In Amsterdam se hawe

sterf daar matrose

vol bier, na 'n drama

in die eerste oggendlig.

In Amsterdam se hawe

word daar matrose gebore

in die taai hitte

van die loom oseaan.

Afrikaanse liriekomsetting:

Op die Amsterdamkaai

Sing matrose 'n lied 
Oor ' $n$ ver vaargebied

Waar nog droomwinde waai

Op die Amsterdamkaai

Slaap matrose so slap

Soos bravades van lap

Van hul drifte ontlaai

Op die Amsterdamkaai

As die dagbreek al kom

Kom matrose nog om

In 'n dronkmansbohaai

Op die Amsterdamkaai

Sien matrose die lig

Hulle adem verlig

Weer die seewind se taai.

Hierdie aanhaling is terselfdertyd 'n goeie voorbeeld van hoe Brel (veral sintaktiese) herhalingstrukture, byvoorbeeld parallelismes en anafore, benut om onder meer kontraste te beklemtoon. In onder meer Afrikaanse bronne, soos De Klerk et al. (1976:546), Gräbe (1984:211-241) en Aucamp (1984:58-61), word sulke herhalingstrukture uitgesonder as onontbeerlike boumiddele in veral die digkuns, byvoorbeeld om indrukke en toonaarde te versterk, om bindings te bewerkstellig, ironieë te laat uitstaan en - op 'n meer banale vlak - vaslegging vir die vertolker te vergemaklik.

Omdat lirieke gewoonlik toegankliker as gedigte is, sou dubbelsinnighede, woordspel en neologistiese of funksieverwisselende woordgebruik gereken kon word tot dieselfde kategorie as ontlenings aan ander tale. Volgens Aucamp (1984:53) kan dit maklik as vervreemdend of aanstellerig ervaar word. Brel het egter nie daarvan teruggedeins om sulke taalverskynsels te benut nie.

Die vriendskaphuldigingslied "Jojo" bevat 'n tweetal voorbeelde. Die eerste strofe begin in Frans soos volg:

Jojo,

Voici donc quelques rires

Quelques vins quelques blondes.

Letterlik vertaal staan daar:

Jojo,

hier's 'n paar glimlagte,

'n paar wyne en 'n paar blondes. 
Die woord blondes kan drie betekenisse hê: blondines, (pils-)biere of sigarette (van "blonde" tabak) - drie tydverdrywingsmiddele waarvan sowel Brel as George Pasquier hulle graag bedien het. In die konteks van die liedgeheel lyk laasgenoemde na die waarskynlikste bedoelde betekenis, aangesien die (verbeelde) gesprek wat die subek met die gestorwe Jojo voer die teenwoordigheid van ander mense waarskynlik uitsluit. Die verwysing na "'n paar wyne" verminder die waarskynlikheid dat bier bedoel word, omdat dit 'n soort oortolligheid van een soort vermaak sou impliseer. Daarom is op die volgende Afrikaanse liriekomsetting van die bepaalde teksgedeelte besluit:

$$
\begin{aligned}
& \text { Jojo, } \\
& \text { ek het grappe gebring } \\
& \text { sigarette en wyne. }
\end{aligned}
$$

In die derde herhaling van die refrein in "Jojo" gebruik Brel die uitdrukking tu frères encore (letterlik "broer jy nog", dit wil sê "bly jy my broer"), waarin die werkwoord frérer neologisties afgelei is van die selfstandige naamwoord frère ("broer"). In die Afrikaanse liriekoorsetting is die uitdrukking vlam broerskap hoog gebruik.

\subsection{Hegte klankbindings}

'n Verdere kenmerkend digterlike werktuig waarmee Brel meermale besondere effekte bereik, is woordklank. Allerlei rymvorms (eind- en binneryme; vol- en halfryme; alliterasies, akkonsonansies en assonansies) is in sy chansons terug te vind. Die benutte herhalingstrukture wat hierbo genoem is, dra uiteraard tot hierdie effekte by: binding, ritmisering, beklemtoning, kontrastering en derglike meer.

Ons het ons uit die staanspoor voorgeneem om, al is dit by wyse van kompenserende ekwivalensie, so ver moontlik die rympatrone en klankspel wat Brel benut het, te eerbiedig.

Die bekende "Le plat pays"/"My lae land" is hiervan 'n uitstaande voorbeeld, maar aan die besonderhede van dié lied sal ons, vanweë die ruimteperke wat op enkelartikels gestel word, in 'n opvolgartikel aandag gee.

Onses insiens het Brel nie altyd ontkom aan die gevaar waarop Aucamp (1984:56) wys nie, naamlik om te "oorkompenseer met klankverkennings en -ontginnings" juis as gevolg van die beperking wat die eis van toeganklikheid op die liriekskrywer plaas om al die subtiliteite van die poësie as genre te kan benut. Ter illustrasie die tweede strofe uit "Les timides"/"Die bedeesdes". In die oorspronklike 
Frans werk Brel met veral twee eindrymklanke, wat stafrymmatig in onderskeidelik die tweede tot sesde en die agste tot dertiende versreëls benut word:

\section{Les timides}

Suivent l'ombre

L'ombre sombre

De leur ombre

Seule la pénombre

Sait le nombre

De leurs pudeurs de Levantin

Ils se plissent

Ils pâlissent

Ils jaunissent

Ils rosissent

Ils rougissent

S'écrevissent

Une valise dans chaque main.

Dit kan letterlik soos volg in Afrikaans vertaal word:

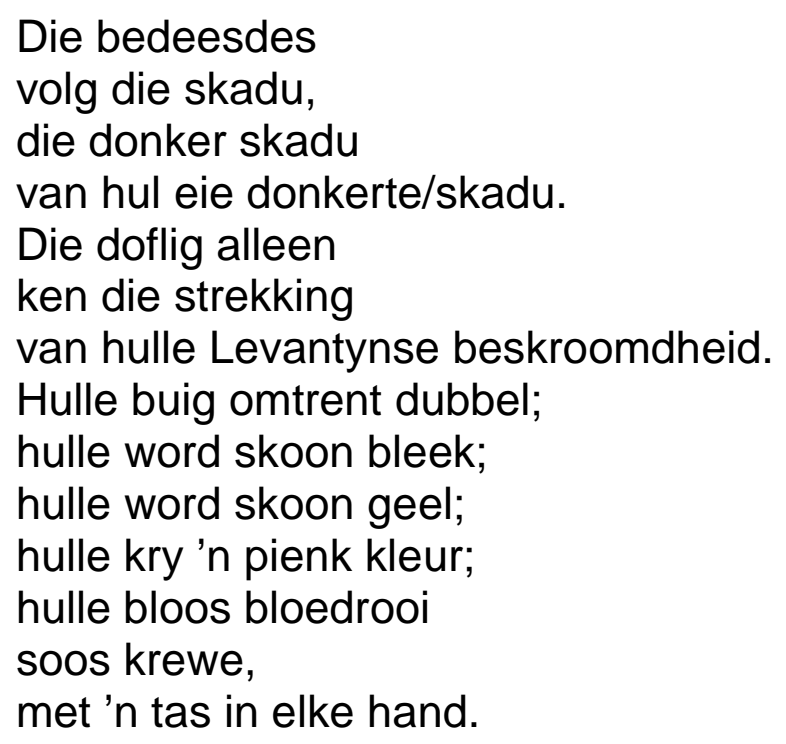

(Die Levant, waarvan "Levantyns" of "Levants" die adjektiwiese afleiding is, is "die oostelike deel van die Middellandse See met sy eilande en aanliggende lande"; Odendal \& Gouws, 2005:664.)

Die strewe deur Brel is om die beskroomdheid en huiwerigheid van die "bedeesdes" vormlik vas te vang, eerstens deur die hortende effek van die kort versreëls, maar ook deur die benutting van die stuitend-nadruklike stafrym. In versreëls 2-4 van hierdie strofe gee dit aanleiding tot die spel met die byna sinonimiese l'ombre en sombre, wat wel as suggestief van die huiweringsgedagte geag kan word, maar wat tog ietwat toutologies aandoen - soos inderdaad ook die 
verwysing na die verskillende kleure wat die bedeesdes se gelate aanneem in versreëls 9-12.

In die Afrikaanse liriekomsetting het ons gekies vir allerlei halfrymvorms, pleks van die volle stafryme, om die huiweringseffek te help vergestalt. Dit het aan ons die vryheid besorg om van te veel toutologie weg te stuur.

Die bedeesdes

volg hul skadu's

die gedaantes

van wesenloosheid

Net die skemer

weet vir seker

al die redes

vir hul skroom

Hul maak buigings

en verskonings

bloos skakerings

van felle kleure

Hul wil liewer net

hulle gang gaan

met ' $n$ tas in elke hand.

\subsection{Verikoniseringsdrif}

Uit wat in die voorafgaande paragrawe geskrywe staan, kan afgelei word dat Brel in sy chansonskryfwerk meermale 'n strewe openbaar wat Bronzwaer (1990:99) as 'n verikoniseringsdrif bestempel, en wat juis kenmerkend van veral poëtiese taalgebruik en vormgewing is (Bronzwaer, 1990:97; in aansluiting by Lotman, 1977). Ruimte ontbreek hier egter om die ikonisiteitsbegrip in besonderhede te verklaar. Ons volstaan deur oorkoepelend op te merk dat dit gaan om die "demonstratiewe" en derhalwe sterker geloofbaarmakende wyse waarop talige, stilistiese, verstegniese en vormlike middele benut word om een of ander "gelykenis" met die semantiese aspekte van byvoorbeeld die gedig te vertoon, sodat die "boodskap" van die gedig hierdeur medegekonstitueer én -gefasiliteer word. (Vgl. Odendaal, 1997:39-40, 61-67, vir 'n meer uitvoerige bespreking van die ikonisiteitskonsep.)

Die hortend-ritmiese versifikasie en stafrymspel in "Les timides", wat die skroom en huiwerigheid van die bedeesdes help suggereer, is voorbeelde van verikoniserende vormgewing. In "Amsterdam" onderskraag die reëlmatige anaforiese en parallelistiese herhalings die indruk van onvergenoegbare lusteviering in allerlei gedaantes deur 
die seelui, sodat die ironiese kontraste tussen hulle verwagtings en dit wat hulle uiteindelik kry, terselfdertyd beklemtoon word. Voorts strook die benutting van die anapestiese metriese patroon (wat ooreenkom met die walsritme in musiek) met die verwysing na die "warrelwindwals" wat die matrose met die haweprostitute dans. Op omvangryker skaal kan Brel se vindingryke benutting van veral paradoks en ironie as stylfigure genoem word, wat ikonies-onderskragend werk ten opsigte van die genoemde ontwapenende mengsel van eerlikheid oor en deernis met die mens, en waaruit sy satiriese betrokkenheid by die menslike toestand blyk.

Bogenoemde enkele voorbeelde van die benutting van verikoniserende elemente in Brel se chansontekste maak dit reeds duidelik dat sulke elemente op sowel mikrotekstuele vlak (klank, woordbou, sinsbou en versifikasie, prosodie, tipografie, intertekstualiteit, beeldspraak en stylfigure) as op medium- en makrotekstuele vlakke (teksreeksvorming, groepering van tekste in afdelings, bundels of albums, en uiteindelik in oeuvreverband) gesoek sou kon word (Odendaal, 1997:90).

\section{Ten slotte}

Bostaande kort oorsig lewer oortuigende bewys daarvan dat Brel se chansontekste dikwels weens hulle digterlike kwaliteite uitmunt. Daardeur wen hierdie liedere met hulle universeel-menslike tematiek ruim aan trefkrag.

Met die vertaling van hierdie bespreekte dertien chansons van "Grand Jacques", 14 asook met die vermelde verdere vertalings, hoop ons om 'n gehaltebydrae tot die Afrikaanse (ligte-) musiektoneel te lewer. Delisle en Woodsworth (1995:1919-228) wys tereg op die interkulturele verrykingswaarde wat vertaling oor die eeue heen kon hê.

... in so 'n mate dat 'n mens sou kon sê dat die ontstaan van moderne nasionale letterkundes, en dié van minderheidstale in die besonder, dikwels teruggevoer kan word na vertalings van oorspronklike tekste uit toonaangewende letterkundige stelsels (Naudé, 2001:188).

14 'n Ironiese bestempeling deur homself in 'n chanson met juis sodanige titel (uit 1955). Vergelyk ook die 1988-album Grand Jacques (Barclay 816720.2), wat 'n keur uit sy vroeëre werk bevat. Dié bestempeling het intussen wydverspreide inslag in die Franstalige wêreld sowel as in die Lae Lande gekry, sónder die oorspronklike ironiese newetone. 
Dit is redelik algemene kennis dat veral die Afrikaanse ligtemusiek tans ' $n$ bloeitydperk beleef. 15 Ons pretendeer dus glad nie om iets aan die gang te wil sit wat klaarblyklik reeds volstoom funksioneer nie. Maar miskien kan die voordeel wat Hennie Aucamp (1984:18) vir die vertaler van gehalteliedtekste in die vertaalproses voorsien, naamlik die "bybring" van "heelwat 'fabrieksgeheime' op 'n konkrete manier", hier geld vir (voornemende) Afrikaanse liedmakers wat die onderhawige Brel-vertalings te lese of te hore kry.

\section{Geraadpleegde bronne}

ANTHIERENS, J. 1998. Jacques Brel: de passie en de pijn. Amsterdam: Van Veen.

AUCAMP, H. 1977. Die lewe is 'n grenshotel: ryme vir pop en kabaret. Kaapstad: Tafelberg.

AUCAMP, H. 1984. Woorde wat wond: geleentheidstukke oor randkultuur. Kaapstad: Tafelberg.

BREL, J. 1988. Grand Jacques. Parys: Barclays. (Barclays 816720.2.) [CD]

BRERETON, G. 1966. A short history of French literature. 5th print. Harmondsworth: Penguin.

BRONZWAER, W. 1990. Poëzie en iconiciteit. Forum der letteren, 31(2):93103.

CLOUZET, J. \& CLOUZET, A. 2003. Jacques Brel: poésie et chansons. Paris: Seghers.

DE KLERK, P.F., ESTERHUIZEN, B.J., HAMMANN, H.J.R. \& NEETHLING, E.L. 1976. Afrikaans my taal: standerds 9 en 10; Afrikaans (Hoër Graad). 2e druk. Kaapstad: Miller.

DE VILLIERS, C. 2004. Handgemaak. Johannesburg: JNS Musiek. (JNSD 121.)

DE VRIES, I. 2007. Letterkunde en integriteit. LitNet. http://www.litnet.co.za Datum van gebruik: 22 Okt. 2007.

DELISLE, J. \& WOODSWORTH, J. 1995. Translators through history. Amsterdam: Benjamins.

DU TOIT, J. 1994. De kleine man. Johannesburg: JNSMusiek. (JNSD 16.) [CD]

DUPRÉ, GUY. 2006. Brel, chansonnier, acteur en ... dichter? http://meander. italics.net/artikelen/artikel.php?txt+1105. Datum van gebruik: 10 Feb. 2006.

GLASER, D. 1963. Interview de Jacques Brel. Discorama ORTF (Office de Radio Diffusion Télévision Française). le 15 septembre.

GRÄBE, I. 1984. Aspekte van poëtiese taalgebruik: teoretiese verkenning en toepassing. Potchefstroom: $\mathrm{PU}$ vir $\mathrm{CHO}$.

GRABERT, W. \& MULOT, A. 1971. Geschichte der Deutschen Literatur. 15. Ed. München: Bayerischer Schulbach Verlag.

15 Johann Rossouw (2007:2) wys op die sentrale simboliese posisie wat Afrikaanse musiek in die Suid-Afrikaanse oudiovisuele sfeer beklee. Laasgenoemde is tans die oorheersende vorm van kultuuroordrag, ook in SuidAfrika. 
HAVEMAN, B. 2005. De driftkikker en de hunkeraar: over Ernst van Altena (1933-1999) als vertaler van Brel en behoeder van de Franse cultuur. (In Brel, J. Mijn vlakke land/Le plat pays: met de vertalingen van Ernst van Altena. Amsterdam: Nijgh \& Van Ditmar. p. 275-280.)

HOUGAARD, K. 1999. Metamorph: contemporary Brel \& Piaf. Johannesburg: JNS Musiek. (JNSD 81.) [CD]

LEO, K. 2004. Sê, c'est la vie. Kaapstad: Leoness Musique. (LMCD 001.) [CD]

LOTMAN, J. 1977. The structure of the artistic text. Translated by Ronald Vroom. Ann Arbor: University of Michigan Press.

MOLIĖRE. s.a. Fuvres complètes. Tome 2. Paris: Nelson.

MONESTIER, M. 1979. Brel - le livre du souvenir. Paris: Tchou.

MOUTON, O., WILSSENS, M., ANTOINE, F. \& REYNEBEAU, M. 2001. Belgium, a state of mind. Tielt: Lannoo.

NAUDÉ, J.A. 2001. Vertaalkunde vandag: 'n oorsig. Tydskrif vir geesteswetenskappe, 41(3):177-194.

NEWMARK, P. 1988. A textbook of translation. Londen: Pergamon.

ODENDAAL, B.J. 1997. Retoriese strategieë in die poësie van T.T. Cloete. Bloemfontein: Universiteit van die Vrystaat. (Ongepubliseerde Ph.D.proefskrif.)

ODENDAL, F.F. \& GOUWS, R.H. 2005. Verklarende Handwoordeboek van die Afrikaanse Taal. 5e uitg. Kaapstad: Pearson Education South Africa.

RAUCH, L. 1980. 'n Jaar in my lewe. Johannesburg: RPM. (RPM 1152.) [Plaatopname]

RAUCH, L. 1997. The Brel album. Johannesburg: Select Musiek. (SELBCD 363.) [CD]

ROSSOUW, J. 2007. Afrikaanse musikale harmonie is nie 'n ydele droom nie. Rapport perspektief: 2, 18 Feb.

STEMMET, J.D. 1992. Chanson. (In Cloete, T.T., red. Literêre terme en teorieë. Pretoria: HAUM. p. 52-54.)

TODD, O. 1984. Jacques Brel une vie. Paris: Laffont.

VAN ALTENA, E. 2005. Jacques Brel, het einde van een tijdperk. (In Brel, J. Mijn vlakke land/Le plat pays: met de vertalingen van Ernst van Altena. Amsterdam: Nijgh \& Van Ditmar. p. 7-12.)

VAN DEN BERG, H. 2007a. (H)erman van den Berg sing Brel in Afrikaans. Johannesburg. (hvdb 004.) [CD]

VAN DEN BERG, H. 2007b. Herman van den Berg: Brel in Afrikaans. Benelux: Tussen kontinente. (MWCD 3029.) [CD]

VAN GORP, H., GHESQUIERE, R., DELABASTITA, D. \& FLAMEND, J. 1993. Lexicon van literaire termen. $4 \mathrm{e} d r$. Groningen: Wolters-Noordhoff.

WELLEK, R. \& WARREN, A. 1980. Theory of literature. 3rd ed. Middlesex: Penguin.

WIKIPEDIA. 2007. Jacques Brel. http://nl.wikipedia.org/wiki/Jacques_Brel Datum van gebruik: 10 Jan. 2007.

\section{Kernbegrippe:}

Afrikaanse vertaling

Brel, Jacques

chanson

literêre kwaliteite 


\section{Key concepts:}

Afrikaans translation

Brel, Jacques

chanson

literary qualities 